DIGITAL COMMONS
@ UNIVERSITY OF SOUTH FLORIDA

Volume 2

Issue 2 Volume 2.2 (Fall 2012): Open Access

\section{ABO: Interactive Journal for Women in the Arts, 1640-1830}

2012

\title{
Stuart Women Playwrights, 1613-1713, by Pilar Cuder-Domínguez
}

R. Mark Jackson

Angelo State University, rjackson14@angelo.edu

Follow this and additional works at: https://digitalcommons.usf.edu/abo

Part of the Dramatic Literature, Criticism and Theory Commons, Educational Methods Commons, Feminist, Gender, and Sexuality Studies Commons, and the Literature in English, British Isles Commons

\section{Recommended Citation \\ Jackson, R. Mark (2012) "Stuart Women Playwrights, 1613-1713, by Pilar Cuder-Domínguez," ABO: Interactive Journal for Women in the Arts, 1640-1830: Vol.2: Iss.2, Article 14. \\ http://dx.doi.org/10.5038/2157-7129.2.2.14 \\ Available at: https://digitalcommons.usf.edu/abo/vol2/iss2/14}

This Reviews is brought to you for free and open access by Digital Commons @ University of South Florida. It has been accepted for inclusion in ABO: Interactive Journal for Women in the Arts, 1640-1830 by an authorized administrator of Digital Commons @ University of South Florida. For more information, please contact digitalcommons@usf.edu. 


\section{Stuart Women Playwrights, 1613-1713, by Pilar Cuder-Domínguez}

\section{Keywords}

Anne Finch, Aphra Behn, Catherine Trotter, Delarivier Manley, Elizabeth Cary, female playwrights, Jane Wiseman, Margaret Cavendish, Mary Pix, review, Stuart, Stuart women playwrights, tragedy, tragicomedy

\section{Creative Commons License} (c) () $\odot$

This work is licensed under a Creative Commons Attribution-No Derivative Works 3.0 License. 
Pilar Cuder-Domínguez. Stuart Women Playwrights, 1613-1713. Burlington: Ashgate, 2011. \$99.95. 148pp. ISBN 9787074667131.

\section{Reviewed by R. Mark Jackson, The University of Alabama}

The scope of this short and captivating book is tighter than the title suggests: not all genres of plays by Stuart women but rather tragedies and tragicomedies exclusively; not manuscripts but only published plays, whether staged or not; and, finally, not the many translations and adaptations from classical and continental sources but only original works. Cuder-Domínguez's intention, defended in a pithy and remarkably straightforward first chapter, is to illumine a dark recess of feminist criticism, and that is the relative neglect of two genres that many women of the period attempted. More particularly, her purpose is to contribute to the "full genealogy of women-authored works" (8) by acknowledging the individual "social, intellectual, and/or formal" (13) uses of tragedy and tragicomedy for each writer while attending to recurrent questions and concerns that refract much of her own, clearly avowed debts to cultural materialism, feminism, and post-colonialism: textually embedded political ideologies, the gendered politics behind the material production of literature, and the analogues and disruptions between constructions of gender and ethnicity.

The terminus ab quo of this study is the publication date of the first tragedy by a Stuart woman, Elizabeth Cary's The Tragedy of Mariam, Queen of Jewry (1613). Unlike much analysis of this closet drama, Cuder-Domínguez's concentrates on its many minor characters, wishing to avoid an "inexact conflation of life and literature" (20) that results from biographical criticism that tracks Mariam too closely. She argues that the play is largely about social fractures that occur within the overlapping and unstable categories of gender and race. A major point of this chapter seems to be to underscore the play's smudging of the typically gendered notions of passivity and activity and to re-orient Mariam's selfdefeating "lack of drive" (27) by the success of such "deviant" female characters as Doris, Alexandra, and Salome, whom her inactivity excites. However, Cuder-Domínguez also observes, though more briefly, racial undercurrents. In a play in which Mariam insists upon her racial superiority over the dark Idumean Salome, Cuder-Domínguez reminds us oppositions of race cannot be extricated from oppositions of class. The next chapter divides its analysis between three plays by Margaret Cavendish published in her 1662 folio. Cuder-Domínguez groups The Unnatural Tragedie and Youths Glory and Deaths Banquet as tragedies and separates Bell in Campo as a tragicomedy_-potentially a controversial choice given that only one carries a generic label and critics have directly contested the generic assignment of Bell in Campo. Cuder-Domínguez, however, is less concerned with the markers of genre than with the ways in which the three plays imagine the choices available to their female characters. Although she does not raise this point explicitly, her organization highlights a gradual tempering of her key concept "claustrophobia" as she moves from one play to the next. In the incest-play The Unnatural Tragedie, "women have nowhere to go outside the home, the very site where they are objects of abuse, violence, or neglect" (43). In Youths Glory and Deaths Banquet, domestic confinement is not quite the case, at least not at first glance. Lady Sanspareille wins acclaim lecturing in the public sphere before her untimely death of illness; however, her self-direction is more apparent than real because all of her successes occur under the vigilance of her father and hence "within the bounds of patriarchal authority" (45). In Bell in Campo, Lady Victoria momentarily escapes and subverts that authority when she leads an army of women into battle in order to refute men's assertions that women are unsuited for public action, but Cuder-Domínguez finds a limit to that heroism in the subplot of the more demure Lady Jantil: for women, militant agency stops at home. As Cuder-Domínguez sums up Cavendish's dramatic career, although Cavendish challenges definitions of women as modest, virginal, and faithful, she goes no further than "proposing a theory of mutuality, or collaboration between the sexes beyond strict gender roles" (52). 
Chapter 4, on Frances Boothby's Mercilia (1670) and four plays by Aphra Behn, discovers in the typical double-plots of tragicomedies a re-working of the so-called "passive/active conundrum" (58) found in The Tragedy of Mariam. Behn's plays, which receive the brunt of the chapter's analysis, perpetuate that dilemma but mix partisan politics into their interrogations of female heroics. In Behn's early tragicomedies The Forc'd Marriage (1670) and The Young King (1679) Cuder-Domínguez finds Behn's monarchical sympathies eclipsing her racial and feminist concerns-a trend continued through the next two plays examined, the revenge tragedy Abdelazer (1676) and Behn's late return to tragicomedy, The Widdow Ranter (1689). Against Susie Thomas's more apologetic reading of Abdelazer, CuderDomínguez proposes that the play's softer attitudes about race come at the price of misogyny, with female characters fitting into the usual casts of passive virgin and deviant whore. Perhaps the closest Behn came to redefining feminine paradigms was, according to Cuder-Domínguez, The Widdow Ranter, especially in its comic plot with the masculine, highly active, and often vulgar Ranter. The comic plot suggests that "certain features cannot be statically assigned to one gender, that they can and should be renegotiated in each particular instance" (79) and, with its New World setting, anticipates the bourgeois woman of the following century. Nonetheless, Cuder-Domínguez argues that even this play undercuts its own feminist message through its comic tone and the bizarreness of its heroine. She surmises that Behn realized that tragicomedy "was impervious to women's heroism" (80).

In her following chapter, the first of two on late Stuart writers, Cuder-Domínguez takes on two sets of tragedies by Mary Pix and Delarivier Manley. The first set, consisting of Pix's Ibrahim (1695) and Almyna (1706) and Manley's Royal Mischief (1695) and The Conquest of Spain (1705), renew early Stuart and Restoration interest in the exoticism of the Mediterranean. Once again, Cuder-Domínguez is concerned with what she refers to as a "double bind" in representations of women: "Patriarchally defined virtue leaves women exposed to male violence, while their agency can only be figured as deviancy" (85). For instance, although Pix and Manley attempt to resolve that common problem in new ways, by portraying female characters as sexual subjects rather than as objects, both end up suborning their preoccupations with both gender and race to their opposed political allegiances, Whig in the case of Pix and Tory in the case of Manley. Political partisanship imbues the second set of plays as well, Pix's Queen Catherine (1698) and Manley's Lucius (1717), two tragedies rooted in English history. Pix's Queen Catherine receives the greater share of analysis and constitutes one of the better parts of CuderDomínguez's book. Although the women in the play seem trapped in the same double bind, Pix also manages "a critique of the masculinist bias of the heroic ethos" (94) by doing something that Manley later does in her play, which is to romanticize the male heroes and tie major historical events to private, emotional conflicts, although Cuder-Domínguez finds in Manley's play less opportunity for female agency and much more coordination with current politics.

The second chapter on the late Stuarts concerns Catherine Trotter exclusively and is Cuder-Domínguez's sharpest. She saves the oft-discussed and much praised Fatal Friendship (1698) for last but handles Trotter's other three tragedies in chronological order: Agnes de Castro (1696), The Unhappy Penitent (1701), and The Revolution of Sweden (1706). In the three historical tragedies, she finds a certain consistency in plot (female characters caught in a dilemma between private feeling and public duty against a background of large-scale political turmoil) that nonetheless defies easy heuristics because each time the dilemma is resolved in a different manner. An inveterate Whig and rationalist, Trotter punishes her two heroines who betray reason and choose private over a public goods, but to uneven degrees - death for Agnes but spiritual penitence for Margarite of Austria-whereas Constantia, heroine of The Revolution of Sweden, who publicly accuses her husband of treason while continuing to live with him at home for duty's sake, receives the reward of a happy ending and stands in contrast to a more masculine woman in the play, Christina, whose abrogation of feminine duties is rendered, according to CuderDomínguez, as "deviant and monstrous" (115). In all, Cuder-Domínguez finds, the three plays evince Trotter's decade-long concern with the strife between public and private spheres and her animus toward transgression. All the same, they show Trotter to be a writer "who wanted to promote a rational approach 
to women's social role, and to encourage finding rational answers to issues of love and passion that, to her mind, so threatened a woman's social status" (116). They also set in relief the fourth play, Fatal Friendship, which Cuder-Domínguez assesses as a departure for Trotter into a more private tragedy featuring a male hero before she returned to the female-centered historical tragedies. She reads this play as more conventional than the other three, with two passive female characters who are "largely contained within a domestic sphere" (119), one of whom, Lamira, bears the hallmarks of a female monster-anger and a loose tongue - and the other of whom, Felicia, embodies stoic inaction. Cuder-Domínguez thus sees the watershed of Trotter's career as The Unhappy Penitent. "From then on," she writes, "her efforts were directed towards showing that a woman's well-regulated life, based on high moral principles, might have an impact beyond her home" (119).

The book concludes with a six-page chapter on two additional tragedies, Jane Wiseman's Antiochus the Great (1701) and Anne Finch's Aristomenes, which provides the book's terminus ad quem. Here, CuderDomínguez is careful to draw comparisons between these last Stuarts with the first, and the WisemanFinch pairing also establishes an obvious contrast between, respectively, Whig and Tory political preoccupations. As in The Tragedy of Miriam, Leodice, the heroine of Antiochus, struggles against her tyrannical husband on behalf of her son yet differs from the parallel case of Doris by trying to get her son to mollify the king's emotions while the king himself bears all the offensive marks that Whigs commonly portrayed in monarchs. Like Margaret Cavendish, Anne Finch finds hope and stability in aristocratic values, writing a play that mixes classical pastoral and epic at the heady time prior to Queen Anne's death, a play in which Cuder-Domínguez glimpses Finch's unquenched desire for a second Stuart restoration.

There are many virtues to this book. Above all, it is an informative, concise, and clear introduction to Stuart women tragedians and a compendious overview of the recent scholarship about them. But the latter quality also points to one of its deficiencies: despite its introductory chapter bemoaning the dearth of scholarly attention paid to seventeenth- and eighteenth-century women tragedians, subsequent chapters never fail to corral scholarly opinions about the plays they interrogate, and often doxography outweighs original insights. When it comes to Cuder-Domínguez's own interpretations as well, it is to her credit that her study of each play or author is so detailed that the book avoids a grand, unifying narrative that probably would oversimplify the history of her subject matter. All the same, the author's concerns seem narrow by the end. Each chapter is directed by either or both of two objectives: measuring where female characters fall on a spectrum between masculine activity and feminine passivity and exposing the political preoccupations that override each author's proto-feminist attitudes. Especially given the introductory chapter, I was expecting to encounter a deeper investigation of the genres tragedy and tragicomedy, and there still seems to be quite a lot of room for such a study although a thorough-going one would require comparisons with pre- and post-Stuart dramas, including comedies, and with male authors-perhaps a heftier project than Cuder-Domínguez wanted to tackle. Those limitations aside, she has written a laudable and useful book. 